\title{
MICROGRAM-LEVEL RADIOCARBON DETERMINATION OF CARBONACEOUS PARTICLES IN FIRN AND ICE SAMPLES: PRETREATMENT AND OC/EC SEPARATION
}

\author{
Fang Cao ${ }^{1,2} \bullet$ Yan-Lin Zhang ${ }^{1,3,4} \bullet$ Sönke Szidat ${ }^{3,4} \cdot$ Alexander Zapf $^{1,3 \dagger} \bullet$ Lukas Wacker $^{5}$ • \\ Margit Schwikowski ${ }^{1,3,4,6}$
}

\begin{abstract}
Carbonaceous particles that comprise organic carbon (OC) and elemental carbon (EC) are of increasing interest in climate research because of their influence on the radiation balance of the Earth. The radiocarbon determination of particulate $\mathrm{OC}$ and EC extracted from ice cores provides a powerful tool to reconstruct the long-term natural and anthropogenic emissions of carbonaceous particles. However, this ${ }^{14} \mathrm{C}$-based source apportionment method has not been applied for the firn section, which is the uppermost part of Alpine glaciers with a typical thickness of up to $50 \mathrm{~m}$. In contrast to glacier ice, firn samples are more easily contaminated through drilling and handling operations. In this study, an alternative decontamination method for firn samples consisting of chiselling off the outer parts instead of rinsing them was developed and verified. The obtained procedural blank of $2.8 \pm 0.8 \mu \mathrm{g} \mathrm{C}$ for $\mathrm{OC}$ is a factor of 2 higher compared to the rinsing method used for ice, but still relatively low compared to the typical OC concentration in firn samples from Alpine glaciers. The EC blank of $0.3 \pm$ $0.1 \mu \mathrm{g} \mathrm{C}$ is similar for both methods. For separation of $\mathrm{OC}$ and $\mathrm{EC}$ for subsequent ${ }^{14} \mathrm{C}$ analysis, a thermal-optical method instead of the purely thermal method was applied for the first time to firn and ice samples, resulting in a reduced uncertainty of both the mass and ${ }^{14} \mathrm{C}$ determination. $\mathrm{OC}$ and $\mathrm{EC}$ concentrations as well as their corresponding fraction of modern for firn and ice samples from Fiescherhorn and Jungfraujoch agree well with published results, validating the new method.
\end{abstract}

\section{INTRODUCTION}

Carbonaceous particles are of increasing interest in climate research because of their influence on the radiation balance of the Earth (IPCC 2007). The total carbon (TC) of carbonaceous particles can operationally be divided into 2 main fractions: weakly refractory organic carbon (OC) consisting of light polycyclic or poly-acidic hydrocarbons; and strongly refractory, highly polymerized, and lightabsorbing elemental carbon (EC) or black carbon (BC) (Pöschl 2005). OC is either emitted as primary aerosol particles or is formed from gaseous precursors as secondary organic aerosols from both non-fossil (i.e. biogenic and biomass burning) and fossil sources, while EC derives from incomplete combustion of fossil fuels and biomass (Pöschl 2005). Ambient concentrations of carbonaceous particles have only been determined for the most recent period, whereas little is known about past natural or anthropogenic emissions of OC and EC. For assessing the role of carbonaceous particles in climate change, the inventories of OC and EC emissions, based on wood and fossil-fuel consumption data, are mostly used. However, these inventories are difficult to obtain, especially in the past, and can vary greatly through time and with location, leading to a large uncertainty. Thus, long-term historical records of concentrations of carbonaceous particles and their sources are in high demand.

${ }^{14} \mathrm{C}$ analysis of $\mathrm{OC}$ and $\mathrm{EC}$ offers a unique and powerful tool for unambiguous distinction between contemporary and fossil sources of carbonaceous particles since the non-fossil carbon contains ${ }^{14} \mathrm{C}$ at a contemporary and known concentration whereas fossil carbon is extinct in ${ }^{14} \mathrm{C}$ due to its half-

\footnotetext{
${ }^{1}$ Paul Scherrer Institute, Villigen, Switzerland.

${ }^{2}$ Guangzhou Institute of Geochemistry, Chinese Academy of Sciences, Guangzhou, China.

${ }^{3}$ Oeschger Centre for Climate Change Research, University of Bern, Switzerland.

${ }^{4}$ Department of Chemistry and Biochemistry, University of Bern, Switzerland.

${ }^{5}$ Laboratory of Ion Beam Physics, ETH, Zurich, Switzerland.

${ }^{6}$ Corresponding author. Email: margit.schwikowski@psi.ch.

† Deceased.
} 
life of $5730 \mathrm{yr}$ (Currie 2000; Szidat et al. 2004a). The ${ }^{14} \mathrm{C}$-based source apportionment tool has not only been applied for atmospheric aerosols (Szidat et al. 2009, these proceedings; Minguillón et al. 2011) but also for carbonaceous particles in ice cores (Jenk et al. 2006, 2007). The concentrations of $\mathrm{OC}$ and $\mathrm{EC}$ as well as the corresponding ${ }^{14} \mathrm{C}$ values in ice cores allow a distinction and quantification of natural (biogenic) and anthropogenic (fossil) contributions to carbonaceous particles in the past, which potentially helps to overcome the lack of long-term carbonaceous particle emission data. However, this method has not been applied to the firn part of ice cores, representing the uppermost $10 \sim 50 \mathrm{~m}$ with lower density and higher porosity. Because of its higher porosity, firn is more prone to contamination during drilling and handling operations than compact ice. Furthermore, the decontamination step used for ice samples, consisting of removing the outer, potentially contaminated layer by rinsing with ultrapure water, cannot be applied to firn. As a consequence, application of the ${ }^{14} \mathrm{C}$ method has been limited to ice samples and has not covered the most recent period overlapping with direct atmospheric data yet.

Separation of $\mathrm{OC}$ and $\mathrm{EC}$ for subsequent ${ }^{14} \mathrm{C}$ analysis is usually achieved by a 2 -step heating process based on different thermal and chemical properties of OC and EC (Szidat et al. 2004b; Zhang et al. 2010). However, with this method both positive (OC charring) and negative artifacts (premature EC removal) have been observed, potentially leading to significant biases in determination of OC and EC mass and their ${ }^{14} \mathrm{C}$ content. This was recently improved by a thermal-optical method (Zhang et al. 2012) utilizing both the special thermal and optical properties of OC and EC, thereby optimizing both the quantification and isolation of $\mathrm{OC}$ and EC.

In this work, we contribute to the aim of establishing long-term historical records of concentrations of carbonaceous particles and their sources with 2 method developments: 1) We introduced an alternative decontamination procedure for application on firn samples consisting of chiselling off the outer parts of the firn instead of rinsing as used for ice samples; 2) We applied the thermal-optical separation of particulate $\mathrm{OC}$ and EC recently developed for aerosol samples (Zhang et al., these proceedings) to firn and ice samples for ${ }^{14} \mathrm{C}$ determination, in contrast to the purely thermal separation that has been used so far.

\section{EXPERIMENTAL}

\section{Sample Preparation}

The method for separating the organic (OC) and elemental carbon (EC) fraction of carbonaceous particles for subsequent ${ }^{14} \mathrm{C}$ analysis was initially developed for ambient aerosol samples (Szidat et al. 2004a,b, 2006, 2009), and has been adapted to ice samples (Jenk et al. 2006, 2007). The original method was modified slightly for the adaptation to firn samples. The overall procedure is illustrated in Figure 1 and described in the following: (a) The firn core sections (about 60-70 cm) are cut into pieces in a cold room $\left(-20^{\circ} \mathrm{C}\right)$ and decontaminated by removal of possibly contaminated outer layers $(\sim 0.5 \mathrm{~cm}$ of the surface) using a stainless steel band saw precleaned with acetone and ultrapure water. (b) The derived samples (150-350 g) are then chiselled with a precleaned stainless steel scalpel to remove possible contamination from the previous step (i.e. dust and/or clothing fibers). Around $10-20 \%$ mass of firn sample is lost during the cutting and decontamination steps. As mentioned above, in the previous method (Jenk et al. 2007) the ice samples were additionally rinsed with ultrapure water to remove potential surface contaminations from sample preparation. However, due to its higher porosity this decontamination step is not applicable for firn, since the water would penetrate into the porous firn, transferring the contamination into the inner part of the samples. This step was therefore omitted. (c) The decontaminated samples are then transferred and stored frozen in prewashed containers (Semadeni, PETG) at $-20^{\circ} \mathrm{C}$ and melted directly before filtration. (d) The partic- 
ulate $\mathrm{OC}$ and $\mathrm{EC}$ in the firn samples are collected on quartz fiber filter (Pallflex Tissuquartz, 2500QAO-UP, $\sim 11 \mathrm{~mm}$ diameter) by filtration. Prior to use, containers and the filtration funnel were rinsed 3 times with $\sim 25 \mathrm{~mL}$ ultrapure water with low TOC impurity in order to reduce the blank. (e) To remove carbonates, the filter is acidified 3 times with $\sim 50 \mu \mathrm{L}$ of $0.2 \mathrm{M} \mathrm{HCl}$ and placed for $\sim 2$ to $3 \mathrm{hr}$ in a laminar flow-box to complete dryness. (f) OC and EC is combusted and separated by a commercial thermal-optical OC/EC analyzer (Model4L, Sunset Laboratory Inc, USA) with a recently developed method (Zhang et al. 2012), which is described in detail in the following section. (g) Finally, the resulting $\mathrm{CO}_{2}$ from the OC/EC analyzer is trapped cryogenically and sealed in glass ampoules for ${ }^{14} \mathrm{C}$ analysis. All materials used in the above steps are almost exclusively made of quartz, glass, stainless steel, and Teflon ${ }^{\circledR}$. All the glass and quartz materials are freshly prebaked for $4 \mathrm{hr}$ at $450{ }^{\circ} \mathrm{C}$ and $850^{\circ} \mathrm{C}$ prior to use, respectively. Other materials (i.e. containers) are cleaned by rinsing several times with ultrapure water. A comparison of the methods applied in this study and previously (Jenk et al. 2006) is summarized in Table 1.

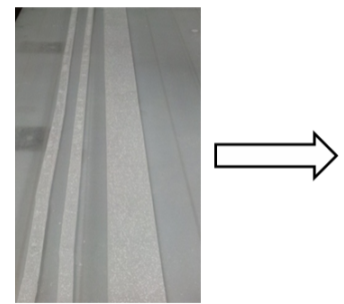

a

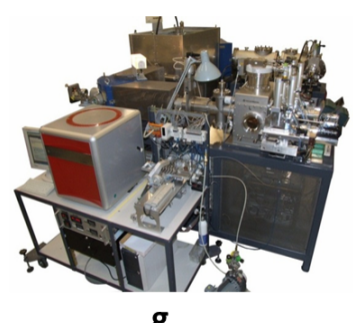

g

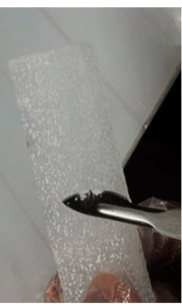

b

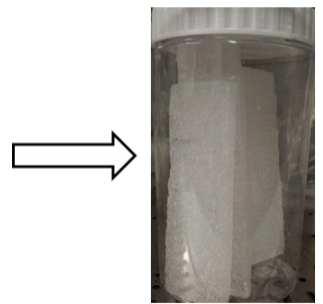

C

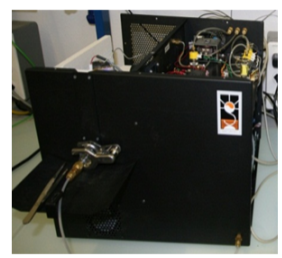

f

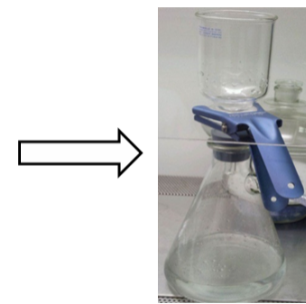

d

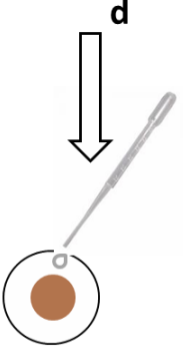

e

Figure 1 Schematic of sample preparation: a) cutting of inner sticks from a firn core; b) chiseling off outer layers; c) melting in precleaned containers; $d$ ) filtering through quartz fiber filter; e) acidification of the filter; f) combustion of OC and EC with the Sunset instrument; g) analysis of ${ }^{14} \mathrm{C}$ with the MICADAS AMS.

Table 1 Comparison of methods applied in this study and previously (Jenk et al. 2006).

\begin{tabular}{lll}
\hline Steps & This study & Jenk et al. 2006 \\
\hline Decontamination & Chiseling & Chiseling and water rinsing \\
Acid treatment & $3 \times 50 \mu \mathrm{L} 0.2 \mathrm{M} \mathrm{HCl}$ on the filter/ & $3 \times 50 \mu \mathrm{L} 0.2 \mathrm{M} \mathrm{HCl}$ on the \\
& $\sim 20 \mathrm{~mL} 1 \mathrm{M} \mathrm{HCl}$ in the melted water & filter \\
$\begin{array}{l}\text { OC/EC separation } \\
\text { and qualification }\end{array}$ & Thermal-optical analysis & Thermal alone analysis \\
$\begin{array}{l}\text { Graphitization } \\
\text { AMS measurement }\end{array}$ & No & Yes \\
\hline
\end{tabular}

${ }^{a}$ A different acid treatment was applied to the 2 ice-core samples from Fiescherhorn glacier (1773-1722 and 1721-1692; see Table 3), which were apparently influenced by a dust event. 


\section{$O C$ and EC Separation and Quantification}

The methodological details of isolation OC and EC with the thermal-optical method (the Swiss_4S protocol) for ${ }^{14} \mathrm{C}$-based source apportionment of ambient aerosol samples was previously described by Zhang et al. (2012). In brief, OC is combusted in pure oxygen at $375^{\circ} \mathrm{C}$ for $\sim 180 \mathrm{~s}$ and subsequently EC is combusted in pure oxygen at $760^{\circ} \mathrm{C}$ for $\sim 120 \mathrm{~s}$ after complete OC combustion and/or evaporation in pure oxygen at $475{ }^{\circ} \mathrm{C}$ for $120 \mathrm{~s}$ and in helium at $650{ }^{\circ} \mathrm{C}$ for $180 \mathrm{~s}$. In contrast to the previously used purely thermal method (Szidat et al. 2004b), on-line monitoring of the optical transmittance of the filters during the thermal treatment in the commercial OC/EC analyzer is applied to evaluate losses or artificial formation of $\mathrm{EC}$ during combustion. The $\mathrm{CO}_{2}$ resulting from the different steps is quantified by a non-dispersive infrared (NDIR) detector and then trapped cryogenically.

\section{${ }^{14} \mathrm{C}$ Analysis}

In the present study, accelerator mass spectrometry (AMS) measurements are carried out with the Mini Carbon Dating System (MICADAS) (Synal et al. 2007) at the Laboratory of Ion Beam Physics of ETH Zurich using a gas ion source (Ruff et al. 2007; Fahrni et al. 2013). This inlet system allows direct injection of the $\mathrm{CO}_{2}$ gas into the AMS, making ${ }^{14} \mathrm{C}$ measurements of carbon masses as low as $3 \mu \mathrm{g} \mathrm{C}$ faster and more reliable (Ruff et al. 2010; Wacker et al. 2013). All ${ }^{14} \mathrm{C}$ results are expressed as fraction of modern $(\mathrm{Fm})$ defined by the fraction of the measured ${ }^{14} \mathrm{C} /{ }^{12} \mathrm{C}$ ratio related to the ${ }^{14} \mathrm{C} /$ ${ }^{12} \mathrm{C}$ ratio of the reference year 1950 (Stuiver and Polach 1977). All reported results are corrected for ${ }^{13} \mathrm{C}$ fractionation and for ${ }^{14} \mathrm{C}$ decay for the time period between 1950 and the year of measurement. Fm values of samples are reported after correction $\left(\mathrm{Fm}_{\text {corrected }}\right)$ for the procedural blank if not stated otherwise, applying the equation below (Sigl et al. 2009):

$$
F m_{\text {corrected }}=\frac{m_{\text {meas }} \cdot F m_{\text {meas }}-m_{P B} \cdot F m_{P B}}{m_{\text {meas }}-m_{P B}}
$$

where $m_{\text {meas }}$ and $F m_{\text {meas }}$ denote the measured carbon mass and Fm of the sample (i.e. OC and EC), respectively. $m_{P B}$ and $F m_{P B}$ denote the average carbon mass and Fm of procedural blanks, respectively.

\section{RESULTS AND DISCUSSION}

\section{Procedural Blank}

For blank assessment and verification of the new firn decontamination method, we attempted producing artificial firn from ice grains formed by freezing droplets, but the contamination resulting from this procedure was too high. Instead, as the best approximation, we used about 300 to $900 \mathrm{~g}$ of artificial ice obtained by freezing of ultrapure water that was treated the same way as described in the experimental sections. The resulting carbon mass $(\mu \mathrm{g} \mathrm{C})$ and the fraction of modern carbon $(\mathrm{Fm})$ of procedural blanks are presented as mean values with a 1 standard deviation in Table 2. Carbon masses of the procedure blank for both $\mathrm{OC}$ and $\mathrm{EC}$ are independent of the masses of the artificial ice, indicating that the contamination did not originate from artificial ice blanks themselves but mainly from the sample preparation steps. The procedural blank for EC is consistent with the previously reported value of $0.3 \pm 0.1 \mu \mathrm{g}$ (Jenk et al. 2007; Sigl et al. 2009), whereas the procedural OC blank is about 2 times higher than the OC blank $(1.3 \pm 0.6 \mu \mathrm{g})$ reported by Jenk et al. (2007), but is still in the same order of magnitude. The higher OC blank indicates that rinsing is more efficient for decontamination than chiseling. To obtain sufficient carbon for ${ }^{14} \mathrm{C}$ determination, $\mathrm{CO}_{2}$ is trapped continuously from 2 subsequent blanks treated with the OC/EC analyzer. Still, Fm could not be measured 


\section{$\mu g$-Level ${ }^{14} \mathrm{C}$ of Carbonaceous Particles in Firn and Ice}

for EC because the carbon mass of the EC blank $(0.32 \pm 0.14 \mu \mathrm{g})$ is by a factor of 10 lower than the limit of detection $(\sim 3-5 \mu \mathrm{g})$ of the AMS measurement. The Fm of the OC procedural blank $(0.81 \pm$ $0.13)$ in this study is substantially higher than the Fm values $(0.60 \pm 0.10)$ published by Jenk et al. (2007), indicating additional contamination from modern sources. Nevertheless, the blanks obtained in this study are relatively low compared to the typical amounts of about $50 \mu \mathrm{g} / \mathrm{L} \mathrm{OC}$ and $15 \mu \mathrm{g} / \mathrm{L}$ $\mathrm{EC}$ found in firn samples from Alpine glaciers (Legrand et al. 2007). For EC, the estimated $\mathrm{Fm}_{\mathrm{PB}}$ from Jenk et al. (2007) is used, i.e. $0.30 \pm 0.30$. The relative contribution of the blank correction to the final uncertainty of Fm ranged from 5\% to $8 \%$ for firn samples from Jungfraujoch.

Table 2 Mass concentrations ( $\mu \mathrm{g})$ and fraction of modern $(\mathrm{Fm})$ of particulate OC and $\mathrm{EC}$ of the procedural blanks obtained in this study.

\begin{tabular}{llllll}
\hline $\begin{array}{l}\text { Sample } \\
\text { label }\end{array}$ & $\begin{array}{l}\text { Mass } \\
(\mathrm{g})\end{array}$ & $\begin{array}{l}\text { Nr of } \\
\text { filters }\end{array}$ & $\begin{array}{l}\text { OC/filter } \\
(\mu \mathrm{g})\end{array}$ & $\begin{array}{l}\text { EC/filter } \\
(\mu \mathrm{g})\end{array}$ & Fm $(\mathrm{OC})$ \\
\hline BK1 & 845 & 3 & $1.78 \pm 0.11$ & $0.20 \pm 0.05$ & \\
BK2 & 340 & 1 & $1.27 \pm 0.15$ & $0.42 \pm 0.08$ & \\
BK3 & 402 & 1 & $2.53 \pm 0.17$ & $0.47 \pm 0.07$ & \\
BK4 & 304 & 1 & $3.42 \pm 0.15$ & $0.41 \pm 0.04$ & \\
BK5 & 578 & 2 & $2.81 \pm 0.10$ & $0.29 \pm 0.05$ & \\
BK6 & 928 & 4 & $3.95 \pm 0.09$ & $0.13 \pm 0.04$ & $0.83 \pm 0.01$ \\
BK7 & 290 & 1 & $2.74 \pm 0.16$ & $0.41 \pm 0.05$ & \\
BK8 & 897 & 3 & $2.40 \pm 0.10$ & $0.57 \pm 0.04$ & $0.67 \pm 0.03$ \\
BK9 & 790 & 3 & $3.44 \pm 0.10$ & $0.21 \pm 0.05$ & $0.97 \pm 0.01$ \\
BK10 & 720 & 2 & $3.23 \pm 0.12$ & $0.13 \pm 0.04$ & $0.78 \pm 0.02$ \\
BK11 & 489 & 2 & $2.65 \pm 0.25$ & $0.29 \pm 0.04$ & \\
Mean & & & $2.75 \pm 0.77$ & $0.32 \pm 0.14$ & $0.81 \pm 0.13$ \\
\hline
\end{tabular}

\section{Validation of the New OC and EC Thermal-Optical Separation}

In order to validate the new decontamination method and the thermal-optical method (the Swiss_4S protocol) for particulate OC and EC separation, we re-analyzed several ice-core samples from Fiescherhorn glacier $(\mathrm{FH})$, which were previously measured with the thermal method by Jenk et al. (2007) (Table 3). The OC mass obtained with the thermal-optical method is higher than with the purely thermal method, whereas the EC mass shows the opposite trend. These new results are considered more reliable compared to the previous method, since the continuous monitoring of transmittance of the filter during analysis with the thermo-optical analyzer prevents biases in OC and EC separation. Nevertheless, there is no significant difference of the corresponding Fm for both OC and EC fractions except for 2 samples from the pre-industrial period. Concerning EC, it should be noted that the EC values reported by Jenk et al. (2007) were simply multiplied by a factor of $2.0 \pm 0.3$ to account for a $50 \pm 8 \%$ loss of EC during the thermal treatment in a muffle furnace for elimination of OC. This resulted in considerably higher uncertainty of the EC mass. In the present study, evolving $\mathrm{CO}_{2}$ is determined continuously together with on-line monitoring of the laser transmittance of the filter, which is used to quantify the EC yield. This resulted in a more accurate determination of EC. The anthropogenic contribution from fossil fuels during the period before 1800 was already significant with about $10 \%$ and $50 \%$ to OC and EC emissions, respectively, according to Jenk et al. (2006). The authors argued that the unexpected $\mathrm{Fm}$ of EC was at least partly biased by old $\left({ }^{14} \mathrm{C}-\right.$ depleted) carbonate from Saharan dust events. Another hypothesis was that gases released from the Saharan dust minerals during combustion interfered during the graphitization step. Here, to fully exclude artifacts from carbonates, the 2 samples from before 1800 were treated differently. In short, after complete melting of the ice samples, the container was rinsed 3 times with $\sim 20 \mathrm{~mL} 1 \mathrm{M} \mathrm{HCl}$ 


\section{F Cao et al.}

instead of $25 \mathrm{~mL}$ ultrapure water, which was then transferred for filtration. As discussed above, graphitization was no longer needed because the gas ion source was used. Since we do not observe a significant anthropogenic contribution for both OC and EC fractions in the pre-industrial samples, we assume that the finding from the earlier work was rather a methodical problem. Therefore, this modified acidification method is highly recommended to be applied for both firn and ice samples to eliminate all the carbonate carbon.

Table 3 Concentrations and fraction of modern (Fm) of particulate OC and EC of ice core samples from Fiescherhorn glacier analyzed by the new method in this study compared to previous results by Jenk et al. (2006).

\begin{tabular}{|c|c|c|c|c|c|c|c|c|c|c|}
\hline \multirow[b]{2}{*}{$\begin{array}{l}\text { Sample } \\
\text { year }\end{array}$} & \multicolumn{5}{|c|}{ This study } & \multicolumn{5}{|c|}{ Jenk et al. 2006} \\
\hline & $\begin{array}{l}\text { Mass } \\
(\mathrm{g})\end{array}$ & $\begin{array}{l}\mathrm{OC} \\
(\mu \mathrm{g} / \mathrm{kg})\end{array}$ & $\begin{array}{l}\mathrm{EC} \\
(\mu \mathrm{g} / \mathrm{kg})\end{array}$ & $\begin{array}{l}\text { Fm } \\
(\mathrm{OC})\end{array}$ & $\begin{array}{l}\text { Fm } \\
\text { (EC) }\end{array}$ & $\begin{array}{l}\text { Mass } \\
(\mathrm{g})\end{array}$ & $\begin{array}{l}\mathrm{OC} \\
(\mu \mathrm{g} / \mathrm{kg})\end{array}$ & $\begin{array}{l}\mathrm{EC} \\
(\mu \mathrm{g} / \mathrm{kg})\end{array}$ & $\begin{array}{l}\text { Fm } \\
(\mathrm{OC})\end{array}$ & $\begin{array}{l}\mathrm{Fm} \\
(\mathrm{EC})\end{array}$ \\
\hline $1928-1933$ & 685 & 49.5 & $23.0 \pm 1.4$ & $0.78 \pm 0.01$ & 0.31 & 957 & $40.5 \pm 0.8$ & $25.1 \pm 0.1$ & $0.77 \pm 0.02$ & 0.31 \\
\hline 1925-1927 & 432 & $42.2 \pm 2.7$ & $22.4 \pm 1.5$ & - & $0.33 \pm 0.02$ & 650 & $30.2 \pm 0.8$ & $22.2 \pm 0.1$ & - & 0.39 \\
\hline 1915-1917 & 279 & $28.9 \pm 0.8$ & $16.2 \pm 0.5$ & $0.83 \pm 0.01$ & $0.33 \pm 0.03$ & 405 & $19.3 \pm 1.5$ & $51.8 \pm 0.5$ & $0.82 \pm 0.07$ & $0.29 \pm 0.02$ \\
\hline 1912-1914 & 301 & $29.4 \pm 0.8$ & $12.6 \pm 0.3$ & $0.83 \pm 0.01$ & $0.30 \pm 0.03$ & 495 & $29.1 \pm 1.3$ & $38.9 \pm 0.4$ & $0.82 \pm 0.04$ & $0.31 \pm 0.02$ \\
\hline $1773-1722$ & 495 & $46.3 \pm 2.3$ & $8.3 \pm 0.3$ & $1.01 \pm 0.01$ & $0.97 \pm 0.04$ & 841 & $29.2 \pm 0.7$ & $12.0 \pm 0.2$ & - & $0.42 \pm 0.10$ \\
\hline $1721-1692$ & 690 & $64.1 \pm 1.8$ & $12.3 \pm 0.3$ & $1.04 \pm 0.02$ & $0.94 \pm 0.02$ & 803 & $44.9 \pm 0.9$ & $13.2 \pm 0.2$ & $0.94 \pm 0.02$ & - \\
\hline
\end{tabular}

\section{Validation of the New Firn Decontamination Method with Samples from Jungfraujoch}

Two firn samples collected on 23 April 2010 at the high-alpine site of Jungfraujoch (JFJ), Switzerland, were used to perform a preliminary test of the new method. These samples were collected from the previous winter snow layer after removing the topmost $10 \mathrm{~cm}$ of snow that contained ash particles from the eruption of the Eyjafjallajökull Volcano in Iceland (Bukowiecki et al. 2011). The snow was sampled in a plastic tube, lined with a polyethylene bag, and compacted with a pusher to mimic a firn core. Average particulate OC and EC concentrations are $32.6 \pm 0.3$ and $5.6 \pm 0.2 \mu \mathrm{g} / \mathrm{kg}$ (Table 4), respectively, which is in the same range as values from Fiescherhorn and Colle Gnifetti glacier (Jenk et al. 2006; Sigl et al. 2009). The Fm values of the corresponding carbon fractions show a fossil contribution of $29 \pm 1 \%, 40 \pm 2 \%$, and $28 \pm 2 \%$ to the OC, EC, and TC, respectively. The Fm of TC is in good agreement with values derived from ambient aerosol samples at European background sites (May et al. 2009) and particles extracted from ice samples from Grenzgletscher (Steier et al. 2006).

Table 4 The concentrations and fraction of modern (Fm) of particulate OC and EC of 2 firn samples from Jungfraujoch (JFJ) collected in 2010.

\begin{tabular}{lllllll}
\hline $\begin{array}{l}\text { Sample } \\
\text { name }\end{array}$ & $\begin{array}{l}\text { Mass } \\
(\mathrm{g})\end{array}$ & $\begin{array}{l}\mathrm{OC} \\
(\mu \mathrm{g} / \mathrm{kg})\end{array}$ & $\begin{array}{l}\mathrm{EC} \\
(\mu \mathrm{g} / \mathrm{kg})\end{array}$ & $\begin{array}{l}\text { Fm } \\
(\mathrm{OC})\end{array}$ & $\begin{array}{l}\text { Fm } \\
(\mathrm{EC})\end{array}$ & $\begin{array}{l}\text { Fm } \\
(\mathrm{TC})\end{array}$ \\
\hline $\mathrm{JFJ}-01$ & 241 & $32.9 \pm 3.0$ & $5.4 \pm 0.8$ & $0.80 \pm 0.03$ & $0.68 \pm 0.02$ & $0.78 \pm 0.04$ \\
$\mathrm{JFJ}-02$ & 323 & $32.3 \pm 3.6$ & $5.8 \pm 0.7$ & $0.77 \pm 0.02$ & $0.66 \pm 0.03$ & $0.75 \pm 0.04$ \\
\hline
\end{tabular}

\section{CONCLUSION}

A new decontamination method consisting of chiseling instead of rinsing was developed for determining the concentrations and ${ }^{14} \mathrm{C}$ content (fraction of modern) of extracted particulate $\mathrm{OC}$ and $\mathrm{EC}$ fractions of carbonaceous particles in firn samples in order to account for the higher porosity of firn compared to ice. The procedural OC blank is a factor of 2 higher compared to the rinsing method. Nevertheless, the OC blank is sufficiently low for analyzing ${ }^{14} \mathrm{C}$ in samples from mid- and low-latitude glaciers with relatively high concentrations of carbonaceous particles. By using a new thermal- 


\section{$\mu g$-Level ${ }^{14} \mathrm{C}$ of Carbonaceous Particles in Firn and Ice}

optical separation of OC and EC instead of the previously used purely thermal method for subsequent ${ }^{14} \mathrm{C}$ analysis, possible biases for mass and ${ }^{14} \mathrm{C}$ determination of $\mathrm{OC}$ and $\mathrm{EC}$ from losses or artificial formation of $\mathrm{EC}$ during analysis were potentially reduced. The results on firn samples from the Jungfraujoch site suggest contemporary sources (biomass burning and/or biogenic) contribute higher than fossil sources to both OC and EC fractions.

\section{REFERENCES}

Bukowiecki N, Zieger P, Weingartner E, Juranyi Z, Gysel M, Neininger B, Schneider B, Hueglin C, Ulrich A, Wichser A, Henne S, Brunner D, Kaegi R, Schwikowski M, Tobler L, Wienhold FG, Engel I, Buchmann B, Peter T, Baltensperger U. 2011. Ground-based and airborne in-situ measurements of the Eyjafjallajökull volcanic aerosol plume in Switzerland in spring 2010. Atmospheric Chemistry and Physics 11:10,011-30.

Currie LA. 2000. Evolution and multidisciplinary frontiers of ${ }^{14} \mathrm{C}$ aerosol science. Radiocarbon $42(1): 115$ 26.

Fahrni SM, Wacker L, Synal HA, Szidat S. 2013. Improving a gas ion source for ${ }^{14} \mathrm{C}$ AMS. Nuclear Instruments and Methods in Physics Research B 294:320-7.

Intergovernmental Panel on Climate Change (IPCC). 2007. Climate Change 2007: The Physical Science Basis: Contribution of Working Group I to the Fourth Assessment Report of the Intergovernmental Panel on Climate Change. Solomon S, Qin D, Manning M, Chen Z, Marquis M, Averyt KB, Tignor M, editors. Cambridge: Cambridge University Press.

Jenk TM, Szidat S, Schwikowski M, Gäggeler HW, Brütsch S, Wacker L, Synal H-A, Saurer M. 2006. Radiocarbon analysis in an Alpine ice core: record of anthropogenic and biogenic contributions to carbonaceous aerosols in the past (1650-1940). Atmospheric Chemistry and Physics 6:5381-90.

Jenk TM, Szidat S, Schwikowski M, Gäggeler HW, Wacker L, Synal H-A, Saurer M. 2007. Microgram level radiocarbon $\left({ }^{14} \mathrm{C}\right)$ determination on carbonaceous particles in ice. Nuclear Instruments and Methods in Physics Research B 259(1):518-25.

Legrand M, Preunkert S, Schock M, Cerqueira M, Kasper-Giebl A, Afonso J, Pio C, Gelencsér A, Dombrowski-Etchevers I. 2007. Major 20th century changes of carbonaceous aerosol components (EC, WinOC, DOC, HULIS, carboxylic acids, and cellulose) derived from Alpine ice cores. Journal of Geophysical Research 112: D23S11, doi:10.1029/ 2006JD008080.

May B, Wagenbach D, Hammer S, Steier P, Puxbaum H, Pio C. 2009. The anthropogenic influence on carbonaceous aerosol in the European background. Tellus $B$ 61(2):464-72.

Minguillón MC, Perron N, Querol X, Szidat S, Fahrni SM, Alastuey A, Jimenez JL, Mohr C, Ortega AM, Day DA, Lanz VA, Wacker L, Reche C, Cusack M, Amato F, Kiss G, Hoffer A, Decesari S, Moretti F, Hil- lamo R, Teinilä K, Seco R, Peñuelas J, Metzger A, Schallhart S, Müller M, Hansel A, Burkhart JF, Baltensperger U, Prévôt ASH. 2011. Fossil versus contemporary sources of fine elemental and organic carbonaceous particulate matter during the DAURE campaign in Northeast Spain. Atmospheric Chemistry and Physics 11:12,067-84.

Pöschl U. 2005. Atmospheric aerosols: composition, transformation, climate and health effects. $A n$ gewandte Chemie International Edition 44(46):752040.

Ruff M, Wacker L, Gäggeler HW, Suter M, Synal H-A, Szidat S. 2007. A gas ion source for radiocarbon measurements at $200 \mathrm{kV}$. Radiocarbon 49(2):307-14.

Ruff M, Fahrni S, Gäggeler HW, Hajdas I, Suter M, Synal H-A, Szidat S, Wacker L. 2010. On-line radiocarbon measurements of small samples using elemental analyzer and MICADAS gas ion source. Radiocarbon 52(4):1645-56.

Sigl M, Jenk TM, Kellerhals T, Szidat S, Gäggeler HW, Wacker L, Synal H-A, Boutron C, Barbante C, Gabrieli J, Schwikowski M. 2009. Towards radiocarbon dating of ice cores. Journal of Glaciology 55(194): 985-96.

Steier P, Drosg R, Fedi M, Kutschera W, Schock M, Wagenbach D, Wild EM. 2006. Radiocarbon determination of particulate organic carbon in non-temperated, Alpine glacier ice. Radiocarbon 48(1):69-82.

Stuiver M, Polach HA. 1977. Discussion: reporting of ${ }^{14} \mathrm{C}$ data. Radiocarbon 19(3):355-63.

Synal H-A, Stocker M, Suter M. 2007. MICADAS: a new compact radiocarbon AMS system. Nuclear Instruments and Methods in Physics Research B 259(1): $7-13$.

Szidat S, Jenk TM, Gäggeler HW, Synal H-A, Fisseha R, Baltensperger U, Kalberer M, Samburova V, Reimann S, Kasper-Giebl A, Hajdas I. 2004a. Radiocarbon $\left({ }^{14} \mathrm{C}\right)$-deduced biogenic and anthropogenic contributions to organic carbon (OC) of urban aerosols from Zürich, Switzerland. Atmospheric Environment 38(24):4035-44.

Szidat S, Jenk TM, Gäggeler HW, Synal H-A, Hajdas I, Bonani G, Saurer M. 2004b. THEODORE, a two-step heating system for the EC/OC determination of radiocarbon $\left({ }^{14} \mathrm{C}\right)$ in the environment. Nuclear Instruments and Methods in Physics Research B 223-224:829-36.

Szidat S, Jenk TM, Synal H-A, Kalberer M, Wacker L, Hajdas I, Kasper-Giebl A, Baltensperger U. 2006. Contributions of fossil fuel, biomass-burning, and bio- 


\section{F Cao et al.}

genic emissions to carbonaceous aerosols in Zurich as traced by ${ }^{14} \mathrm{C}$. Journal of Geophysical Research 111(D7): D07206, doi:10.1029/2005JD006590.

Szidat S, Ruff M, Perron N, Wacker L, Synal H-A, Hallquist M, Shannigrahi AS, Yttri KE, Dye C, Simpson D. 2009. Fossil and non-fossil sources of organic carbon (OC) and elemental carbon (EC) in Goeteborg, Sweden. Atmospheric Chemistry and Physics 9:152135.

Szidat S, Bench G, Bernardoni V, Calzolai G, Czimczik CI, Derendorp L, Dusek U, Elder K, Fedi M, Genberg J, Gustafsson Ö, Kirillova E, Kondo M, McNichol AP, Perron N, Santos GM, Stenström K, Swietlicki E, Ushida M, Wacker L, Vecchi R, Zhang YL, Prévôt ASH. 2013. Intercomparison of ${ }^{14} \mathrm{C}$ analysis of carbonaceous aerosols: Exercise 2009. Radiocarbon, these proceedings, doi:10.2458/azu_js_rc.55.16314.

Wacker L, Fahrni SM, Hajdas I, Molnár M, Synal H-A, Szidat S, Zhang YL. 2013. A versatile gas interface for routine radiocarbon analysis with a gas ion source. Nuclear Instruments and Methods in Physics Research B 294:315-9.

Zhang YL, Liu D, Shen CD, Ding P, Zhang G. 2010. Development of a preparation system for the radiocarbon analysis of organic carbon in carbonaceous aerosols in China. Nuclear Instruments and Methods in Physics Research B 268(17-18):2831-4.

Zhang YL, Perron N, Ciobanu VG, Zotter P, Minguillón MC, Wacker L, Prévôt ASH, Baltensperger U, Szidat S. 2012. On the isolation of OC and EC and the optimal strategy of radiocarbon-based source apportionment of carbonaceous aerosols. Atmospheric Chemistry and Physics 12:10,841-56.

Zhang YL, Zotter P, Perron N, Prévôt ASH, Wacker L, Szidat S. 2013. Fossil and non-fossil sources of different carbonaceous fractions in fine and coarse particles by radiocarbon measurement. Radiocarbon, these proceedings, doi:10.2458/azu_js_rc.55.16278. 